\title{
Project manager's competences game: How does it work?
}

\author{
Inese Sluka \\ Faculty of Business and Economics \\ RISEBA University of Applied Sciences, \\ Riga, Latvia \\ inese.sluka@riseba.lv
}

\begin{abstract}
The project manager's competences play a crucial role in the success of different projects. Based on the Individual Competence Baseline 4th Version ICB4, established by the International Project Management Association, a board game "Sea wolf" Version 4 has been created as a tool for project manager's competences and project management teaching. To develop professional competence, students must understand the essence of the competence, roles and responsibilities of the team members, the necessity of teamwork, as well as project management principles.
\end{abstract}

This study aims to research the results of the project management competences board game "Sea wolf" to clarify the learning outcomes for the participants and further project management teaching.

This study will answer the following research questions, namely:

1) What are the key learning outcomes for the participants of the game?

2) Which competences are understood by the participants best, during the game?

3) What socio-demographic factors for the participants may correlate with the results of the game?

The study was undertaken from November 2018 to January 2019. The game was played by 47 teams, that is 253 participants. The participants were project management students with differing levels of knowledge and experience. The game results were fixed on each team summary page and analysed.

The results show that students improved their teamwork skills, understood the essence of project management competences and basic project management principles. Younger participants and participants with no previous educational education in project management achieved better results.

Keywords - gamification, board game, project manager, competence, ICB4.

\section{INTRODUCTION}

The Project Management Institute indicated growth for the project management industry. More than 15.7 million new project management jobs will be generated in seven industries between 2010 and 2020 [1]. As project managers take on a more expansive role, training and skill development are ever more critical. In project management, internal and external training needs to be created to develop competences, including aspects of collaboration and innovative mindset [2].

As many organisations utilising the project management approach and demand for project managers grows, the importance of standards for the project manager's standards of competence will increase [3]. Individual Competence Baseline 4th Version is the initial competence baseline on which the board game has been created.

The use of games in the learning process is not a new concept, but several studies have proven games to be an effective tool that is becoming more and more popular in education [4]. Games are an ideal environment in which you can make mistakes, encourage thinking out-of-the-box, and also understand the sense of control [5].

There is a lack of studies in using board games to teach project management and project manager's competences.

This paper aims to research the results of the project management competences board game "Sea wolf" to clarify the learning outcomes for the participants and for project management teaching.

The research will answer the following questions: 1) What are the key learning outcomes for the participants of the game?; 2) Which competences are understood by the participants best, during the game?; 3) What socio-demographic factors for the participants may correlate with the results of the game?

This paper is structured as follows: first, the gamification concept and board game principles are described; second, project manager's competences are explained; third, the board game rules are described; and finally, research methodology, results and discussion are presented.

\section{GAMIFICATION AND BOARD GAME}

"Gamification is using game-based mechanics, aesthetics and game thinking to engage people, motivate action, promote earning, and solve problems" [5, p125]. According to Deterding et al., Gamification refers to the "use of design elements characteristic for games in non-gaming contexts" [6, p9]. 
Gamification is not just playing games. Games create a world of imagination that is different from reality. Gamification create reality with game's elements. [7].

The effectiveness of gamification has been observed in different industries as business, technology [8], wellness and health, marketing [9] and others.

Despite the variety of industries, the benefits from gamification are similar: competition, engagement, using knowledge, experience and skills in different environments [10].

Gamification is used in different areas as motivation and work performance [11], engagement through gamification [12], learning [13]. In this paper, gamification focus is on learning with games.

\section{A. Educational games}

Petersen and Ekambaram [14] drew attention to the fact that the methods of training project managers are outdated, which is the reason why many projects still fail. It is important for the project managers to maintain core skills over time and to continually develop skills and knowledge using the latest methods [14] The labour market is displaying high demand for young project managers. Very often, the emphasis is placed on experience, which is what young professionals lack the most, however, not in academic attainment [15].

Kapp provided the game's definition in the educational context. The game is a system which includes such elements as players, their emotional reactions, thinking and challenges, as well as rules, interactivity, feedback a and results [5]. The game's value is that "students have a common understanding of the project. The game helps in this path, providing a common ground to evolve as a group." [16, p23]. It is difficult to create educational content that transfers into real-world skills and knowledge. [17].

\section{B. Board games}

Board games provide a playful, safe and competitive environment in which players can learn from their mistakes because of their shortcomings and failures in achieving the learning objectives [18]. In a board game, participants can see how they relate to other players, who are taking the next turn, what is the overall progress of the game towards successfully finishing [5].

Board games are used for professional training in different areas - healthcare $[19 ; 20]$, language teaching [21], creativity and innovations [22;23], business and marketing [24].

Based on scientific articles, board games are used, but there have only been a few publications about their results. The EBSCO database has published results of "Task Manager Board Game" as a training tool in project management [25].

\section{PROJECT MANAGER'S COMPETENCES}

The project manager's competence is associated with the use of a common professional language and concepts for project management. Competence demonstrates behaviour in the workplace and can be measured with accepted standards [26]

The standard provides a common understanding of the rules, knowledge, skills and activities to achieve the results. The standard is established and approved by a recognized institution [27].

There are several international documents describing the project manager's competences:

1) Project management competency development framework (PMCD) $3^{\text {rd }}$ edition provided by Project management Institute [28]. PMCDF can be described as consisting of three separate dimensions: project management knowledge and performance competence, as well as personal competency. [29].

2) APM Body of Knowledge, $7^{\text {th }}$ edition, provided by Association for Project Management. APM Body of Knowledge includes four areas: context, people, delivery and interfaces [30];

3) Australian National Competency Standards for Project Management provided by the Australian Institute of Project management. The Standards are described in terms of the units of project management: scope, time, cost, quality, human resources, communications, risk, contract and procurement management [31];

4) Individual Competence Baseline $4^{\text {th }}$ Version ICB4, established by the International Project Management Association. [32]

ICB is the initial competence baseline on which the board game was created.

The ICB4 is designed as Eye of the project manager's Competence to create the next generation of project management. 28 competence elements are grouped in three parts [32, p31-32]:

"People competence (10 elements): selfreflection and self-management; personal integrity and reliability; personal communication; relations and engagement; leadership; teamwork; conflict and crisis; resourcefulness; negotiation; results orientation".

"Practice competence (14 elements): project design; goals, objectives, and benefits; scope; time; organisation and information; quality; finance; resources; procurement; plan and control; risk and opportunity; stakeholders; change and transformation; select and balance".

"Perspective competence (5 elements): strategy; governance, structures and processes; compliance, standards and regulations; the informal power and interest; the culture and values".

\section{DESCRIPTION OF THE BOARD GAME}

Boardgame "Sea wolf" is created based on IPMA Individual Competence Baseline for Project, Programme and Portfolio Management version 4.0 (ICB4). The objective of the game is to finish the project in 50 minutes with the least expense. 


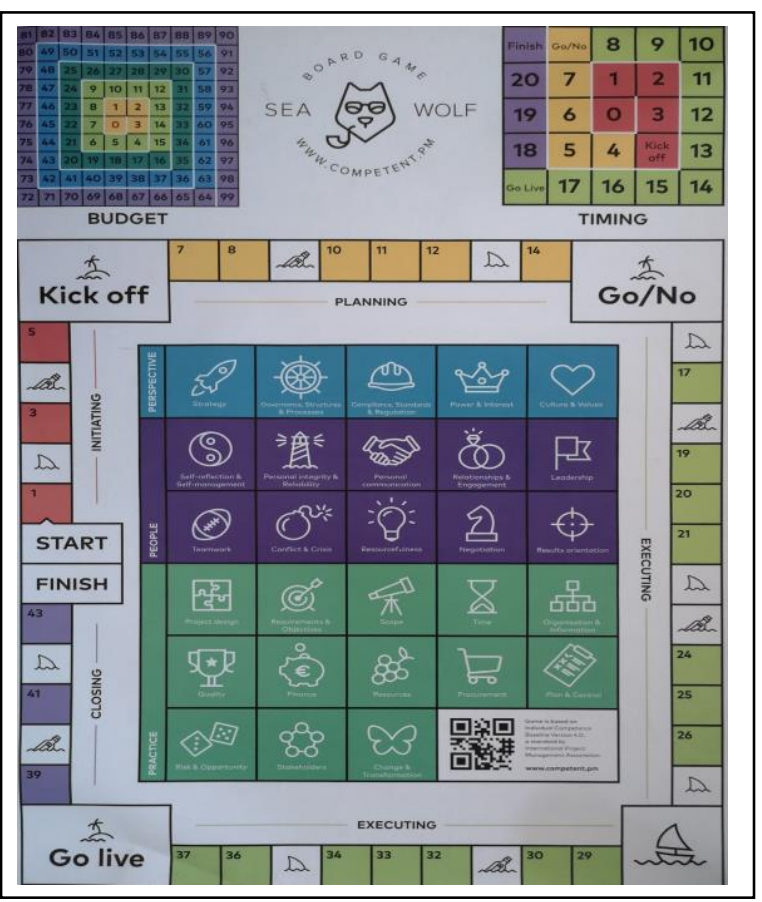

Fig. 1. The field of the board game "Sea wolf"

Before the game, participants have 20 minutes to prepare for the game, that is, be become acquainted with the rules and divided the team roles. A team consists of 6 players with the following roles: Captain or project manager, budget controller, time-keeper, coach, reporter, team spirit keeper.

The game consists of the game board which includes a projected lane of four phases, three intermediate stages, start and finish. An inner field contains 28 competencies. In two corners of the board are a "budget" to count expenses and a "timing" to count the rounds.

Teams will now have 50 minutes to compete to finish the project with the least expenses. Players commence the project, moving along the game field, in turn throwing a die. Teams should count their expenses, turns (rounds) and bonuses on the board. The board is divided into four project phases and three intermediate stages. Players who have reached the intermediate stage of finish, stop there and wait for the remaining players. They act according to their role, can participate in discussions, but not the throwing of dice.

In the project line are places "Risk" and "'Opportunity' cells. A player who enters a Risk or Opportunity cell reads aloud and clearly to the team a situation card from the corresponding phase of the project, without taking the card from the table. The team discuss the situation and within one minute should choose three of the most necessary competences in this situation and with the help of which it is possible to avoid, alleviate or minimise the risk, or to make full use of the opportunity. The player, who has run into this situation, has the right to make a final decision on the choice of the three competences if the team has not reached a shared opinion. During the game, students can use the mobile application competent.pm. When time has run out, the team enter the results and submit a form before discussing the results of the game.

\section{RESEARCH METHODOLOGY}

Both the Qualitative and Quantitative approaches were used to conduct this research study. The quantitative data concerning the participants, their age, education, project management experience and knowledge of the ICB4 competences were obtained by completing an application form before the game. The game results data such as turn bonuses spent budget and the remaining game time was collected after the game.

Qualitative data was collected on completion of the game using feedback forms where the participants wrote the learning outcomes, benefits, and main conclusions concerning the game. The feedback form was not restricted to any questions to obtain the conclusions the participants felt to be the most significant.

The gaming of board game "Sea wolf" took place and the results collected between November 2018 and January 2019. The target audience of the study includes adults from various sectors who acquired project management professional improvement programme at RISEBA University of Applied Sciences. The selection of the participants was random. The aim of the game being used in the teaching process was to make the participants aware of the ICB4 competences. The board game was played by $(n=47)$ teams with a total of $(n=235)$ participants.

The information freely provided by the participants in the feedback forms was grouped based on the content. The responses of each group were analysed using the NVivo word frequency test to find the most frequently mentioned words to explain the most mentioned learning outcomes of the game. The analysis of the quantitative data was carried out using IBM SPSS Statistics.

The following research study questions were answered based on the analysis of the qualitative data: 1) What are the key learning outcomes for the participants of the game?; 2) Which competences do the participants understand best during the game? The following research study questions were answered based on the analysis of the quantitative data: 3) What socio-demographic factors of the participants correlate with the results of the game?

\section{RESULTS AND DISCUSSION}

\section{A. Basic respondent data}

$89 \%$ of the participants were not aware of the Project Manager Competence Guideline (ICB4) before the game; only $11 \%$ of the participants knew the 
competence guideline or had used it. None of the participants had ever played the board game "Sea wolf" before. Table 1 shows the socio-demographic characteristics of the participants in this study. TABLE I. SOCIO-DEMOGRAPHIC CHARACTERISTICS OF THE
PARTICIPANTS (N=235)

\begin{tabular}{|c|c|c|c|}
\hline Characteristic & Values & Frequency & Per cent \\
\hline \multirow[t]{2}{*}{ Gender } & Male & 76 & 32 \\
\hline & Female & 159 & 68 \\
\hline \multirow[t]{4}{*}{ Education } & Secondary & 25 & 11 \\
\hline & $\begin{array}{l}\text { Professional } \\
\text { secondary }\end{array}$ & 16 & 7 \\
\hline & Bachelor & 84 & 36 \\
\hline & Master & 110 & 46 \\
\hline \multirow{3}{*}{$\begin{array}{l}\text { Previous } \\
\text { education in } \\
\text { PM }\end{array}$} & No & 118 & 50 \\
\hline & $\begin{array}{l}\text { Employer } \\
\text { courses }\end{array}$ & 41 & 17 \\
\hline & $\begin{array}{l}\text { Professional } \\
\text { courses }\end{array}$ & 76 & 33 \\
\hline \multirow{4}{*}{$\begin{array}{l}\text { Years of } \\
\text { experience in } \\
\text { PM }\end{array}$} & $0-1$ & 96 & 41 \\
\hline & $2-3$ & 42 & 18 \\
\hline & $4-6$ & 94 & 40 \\
\hline & 7 and more & 3 & 1 \\
\hline \multirow[t]{7}{*}{ Age group } & $20-25$ & 17 & 7 \\
\hline & $26-30$ & 71 & 30 \\
\hline & $31-35$ & 61 & 26 \\
\hline & $36-40$ & 41 & 17 \\
\hline & $41-45$ & 23 & 10 \\
\hline & $46-50$ & 16 & 7 \\
\hline & $51-60$ & 6 & 3 \\
\hline
\end{tabular}

\section{B. Game result analysis}

47 teams participated in the game. Table 2 shows that $49 \%$ of the teams had implemented the project on the $2^{\text {nd }}$ budget level and, $28 \%$ had implemented it on the $1^{\text {st }}$ level, which can be rated as good results.

The time the teams had left until the end of the project differed, and this suggests that the optimal duration of the game was chosen for the participants to manage to complete everything. Only $4 \%$ of the teams completed the game at the last moment.

$45 \%$ of the teams received four bonuses, and this means that all the team members had completed the respective project phase within the expected time. However, 28\%, which is the second-highest indicator, had not managed to complete the phase within the expected time, whereas $17 \%$ of the teams have received an additional bonus for the correct choice of competences in risk situations.

TABLE II. SOCIO-DEMOGRAPHIC CHARACTERISTICS OF THE PARTICIPANTS $(\mathrm{N}=47)$

\begin{tabular}{|l|c|c|c|}
\hline Characteristic & \multicolumn{1}{|l|}{ Values } & Frequency & Per cent \\
\hline Time left in & 0 & 2 & 4 \\
\cline { 2 - 4 } minutes & $1-5$ & 17 & 36 \\
\cline { 2 - 4 } & $6-10$ & 10 & 21 \\
\cline { 2 - 4 } & $11-15$ & 14 & 30 \\
\cline { 2 - 4 } & $16-20$ & 3 & 6 \\
\cline { 2 - 4 } & 30 & 1 & 3 \\
\hline Budget & $0-15$ & 13 & 28 \\
\cline { 2 - 4 } & $16-35$ & 23 & 49 \\
\cline { 2 - 4 } & $36-63$ & 9 & 19 \\
\cline { 2 - 4 } & 65 & 2 & 4 \\
\hline Bonuses & 1 & 6 & 43 \\
\cline { 2 - 4 } & 3 & 13 & 17 \\
\cline { 2 - 4 } & 4 & 8 & \\
\cline { 2 - 4 } & 5 & & \\
\hline
\end{tabular}

The budget is among the key indicators in the game because it is influenced by the number of turns and the choice of the competences to mitigate risk.

Pearson's correlation analysis was carried out to determine the correlation between the budget and the data mentioned in Table 1. Results are shown in Table 3.

TABLE III. PEARSON'S CORRELATION ANALYSIS

\begin{tabular}{|c|c|c|c|}
\hline & & Age & Courses \\
\hline \multirow[t]{2}{*}{ Budget } & $\begin{array}{c}\text { Pearson } \\
\text { Correlation }\end{array}$ &,$- 132^{*}$ & $147^{*}$ \\
\hline & Sig. (2-tailed) & .044 & .024 \\
\hline
\end{tabular}

*. Correlation is significant at the 0.05 level (2-tailed).

The "Budget" result has a weak and negative $(\mathrm{p}=$ ,- 132 , sig=0,04), but statistically significant correlation with the previous educational attainment of participants, i.e. the participants who have not previously attended any courses associated with project management achieve better results in the game's budget result.

Better results for participants who have not previously acquired project management education can be explained by the absence of limitations on past knowledge and the ease of taking new experience. Marcos et al. research results show that social gamification produced even better results even at early stages of the course [4].

The 235 conclusions and learning outcomes provided by the participants regarding the game were coded based on the content. The highest number of statements regarded the following: The competences (82 statement), the team (62 statements) the project (46 statements) and the game in general (45 statements).

The responses in each group of statements were analysed using NVivo to determine the most frequently mentioned words and undertaking further analysis of the content in the statements provided.

The Competences group's word frequency results are shown in Table 4.

TABLE IV. COMPETENCES GROUP WORD FREQUENCY QUERY RESULTS

\begin{tabular}{|l|l|l|}
\hline Word & Count & $\begin{array}{l}\text { Weighted Percentage } \\
(\boldsymbol{\%})\end{array}$ \\
\hline Explanation & 16 & 2,91 \\
\hline Aware & 14 & 2,54 \\
\hline Understanding & 13 & 2,35 \\
\hline
\end{tabular}

The word "competence" as among the ones used most frequently, but it was excluded from the analysis when analysing other words which are important to improve the process of the game and to acquire the competences.

To explain the opinion of the participants in each group, a summary of the meaning of each word is provided in Table 5 . 
TABLE V. EXPLANATION OF MOST FREQUENT WORDS IN COMPETENCE GROUP

\begin{tabular}{|l|}
\hline Explanation \\
\hline -In-depth explanation regarding the competences was missing \\
-I did not know the explanation of the competences \\
-Insufficient explanation of the competences in the application \\
-Explanation required regarding why the particular \\
competence should be used \\
\hline Aware \\
\hline -Helps to get aware of the competences \\
-Helps to get aware of the competences quickly \\
-Necessary to become aware of the competence guideline \\
-Become aware of the competence in greater detail is required \\
\hline Understanding \\
\hline -Common understanding regarding the competences is \\
essential in the team \\
-Supports understanding regarding the competences \\
-Lack of understanding regarding the competences \\
-Understanding would improve by playing multiple times \\
-Understanding of the competences depends on the experience \\
\hline
\end{tabular}

An explanation of the competences as the most frequently mentioned word aligns with the aim of the game, which is to make the participants aware of the competencies. Overall the game provides a remarkable insight into the competences, improves understanding regarding them and, makes it necessary to become aware of them in greater detail.

The participants have had the best understanding of and have been able to make the best use of the competences "Personal Communication", "Conflict and Crisis", "Time", "Leadership", "Strategy" and "Teamwork" during the game.

According to Rumeser and Emsley [33] one of the challenges in project management games is to cover the broad project management knowledge areas. Boardgame "Sea wolf" includes 28 competences from ICB4.

The analysis of the statistical data showed that the teams in which the participants know ICB4 do not achieve better results when compared to teams in which none of the participants has any knowledge of ICB4. The experience of the participants did not demonstrate any associations with the results of the game.

Team group's word frequency results are shown in Table 6.

TABLE VI. TEAM GROUP WORD FREQUENCY QUERY RESULTS

\begin{tabular}{|l|c|c|}
\hline Word & Count & $\begin{array}{l}\text { Weighted } \\
\text { Percentage (\%) }\end{array}$ \\
\hline Teamwork & 20 & 6,82 \\
\hline Decision & 8 & 2,73 \\
\hline Communication & 5 & 1,70 \\
\hline Agreement & 5 & 1,70 \\
\hline
\end{tabular}

To explain the opinion of the participants in each group, a summary of the meaning of each word is provided in Table 7 .
TABLE VII. EXPLANATION OF MOST FREQUENT WORDS IN TEAM GROUP

\begin{tabular}{|l|}
\hline Teamwork \\
\hline -Excellent teamwork \\
-Teamwork improved \\
-Teamwork is important \\
-Teamwork was valuable \\
-Teamwork was efficient \\
\hline Decision \\
\hline -Common decision-making \\
-Ability to make sensible decisions \\
-Trust in decision-making \\
-Quick decision-making \\
-Long discussion interferes with decision-making \\
\hline Communication \\
\hline -Communication skills improved \\
- Communication test for the team \\
- Communication is very important \\
-Communication helps to find out what is in common \\
\hline Agreement \\
\hline -Agreement regarding the competences \\
-Agreement regarding the final choice \\
-Agreement on the terms \\
-Agreement on the decision \\
\hline
\end{tabular}

One of the key benefits in particular from the game was teamwork and its value, significance and efficiency in achievement of a common objective. This result of the research is similar to the results of the research studies conducted by several other authors. Azizan et al. indicate that a board game is one of the key benefits which builds teamwork and helps the participants to become acquainted with each other [23].

Most decisions of project manager are based on "iron triangle" considering time, cost and quality with the principles to ensure project transparency [34]. The game results confirm that decision-taking has an impact on project implementation.

Communication is the most necessary competence in project management which is proved by the game results. Zulch [35] findings illustrate that the project manager's skill to communicate has an impact on the cornerstone areas of project management. Communication competence is necessary to manage project time, costs, scope and quality.

The test of the most frequently used words with the count of 4 was specified for such words as "Cooperation", "Experience", "Discussion" and "Consolidation".

Each participant of the game had their role, but there were only two notes regarding these in the feedback part, that is, that the participants had played their roles and that the playing of the roles had changed during the game. The game is designed so that the final decision regarding the chosen competence is made by the participant who has got to the "Risk" or "Opportunity" cell, thus reducing the influence of the project manager.

The game helps to understand the principles of action of a self-organising team which are most popular in Agile projects.

In a self-organizing team, project management activities are shared among managers, customers and 
team members [36]. All members in the selforganising teams are more closely involved in project management activities.

The time and budget controllers have more essential roles in the game, and the other roles are not demonstrated during the game.

Project group's word frequency results are shown in Table 8 .

TABLE VIII. PROJECT GROUP WORD FREQUENCY QUERY RESULTS

\begin{tabular}{|l|c|c|}
\hline Word & Count & $\begin{array}{l}\text { Weighted } \\
\text { Percentage (\%) }\end{array}$ \\
\hline Success & 12 & 5 \\
\hline Time & 8 & 3,33 \\
\hline Risk & 6 & 2,6 \\
\hline Budget & 5 & 2,08 \\
\hline
\end{tabular}

To explain the opinion of the participants in each group, a summary of the meaning of each word is provided in Table 9.

TABLE IX. EXPLANATION OF MOST FREQUENT WORDS IN TEAM GROUP

\begin{tabular}{|l|}
\hline Success \\
\hline -Success is of great importance in the game \\
-The result of the project depends on the success \\
-Project success consists of several elements \\
\hline Time \\
\hline -Time influences project quality \\
-It is important to balance project time and budget \\
- Project time needs to be planned \\
-Project time is important in each step \\
-It is better to spend time on avoidance of risks \\
- Shortage of time causes stress \\
-Time limitations are bad for discussions \\
\hline Risk \\
\hline - The more risks there are, the larger the project budget \\
- Risk assessment requires more time \\
- It is worth taking risks in the project \\
-More focus necessary on avoidance of risks and less on \\
opportunities \\
\hline Budget \\
\hline -Errors in the project influence the budget \\
- Risks reduce the project budget \\
- The budget needs to be considered at every step throughout the \\
project \\
-It is important to balance project time and budget \\
\hline
\end{tabular}

The key learning outcome is understanding regarding the success in project management, but it should, however, be noted that, in this case, the factor of success is not the same as the traditional definition of project success. In this game, the factor of success is more closely associated with the uncertainty (fortune) in the project, such as the number one gets on the die, the number of times arrival on the "Risk" cell etc.

Time and budget are the basic values that describe the project. During the game, the participants have understood the significance of time and budget in the project as well as the correlation between them.
Analysing the benefits from the game in general, the participants indicated that the board game "Sea wolf':

- helped understand the real situations in the project;

- substantiated the project processes;

- visualised the progress of the project;

- allowed to learn team management;

- taught how to be tolerant and flexible;

- enabled development of individual competence;

- helped become aware of the project management terminology;

- helped learn from mistakes by changing the course of the game;

- was a good tool for learning project management;

- was interesting.

- allowed spending time purposefully.

All the aforementioned factors create a collaborative environment. Collaboration in project management means that we can focus on skills such as stress management, teamwork, team dynamics and stakeholder management apart from theories [16].

\section{CONCLUSIONS}

The results proved that the board game "Sea wolf" is a tool for the improvement of teamwork, becoming more aware of the ICB4 competences and understanding the key principles of project management.

The qualitative study suggested that several improvements would be necessary, including the game summary page should include notes regarding the risk and opportunity indicators in order to be able to analyse them in context with the other game results; a review of the roles of the participants and provision of more accurate indications regarding the involvement of the participants in various phases of the project.

Even though in this game, the teams containing members with previous knowledge of ICB4 did not demonstrate better results, further comparative research studies might be conducted to study the differences between teams where all the members know the ICB4 competences and teams where no members have any knowledge about them.

The study might be continued as a quantitative study in which the influence of various indicators on the results of the game could be analysed. The outcomes of this game displayed the correlations between the results of the game and the age and previous knowledge of the participants, which should be researched in greater detail.

\section{REFERENCES}

[1] Project management institute (PMI), "Talent Gap Report Project management between 2010+2020", 2013. Available at: $\quad$ https://www.pmi.org//media/pmi/documents/public/pdf/business-solutions/projectmanagement-skills-gap-report.pdf

[2] Project management institute (PMI), "The Project Manager of the Future. Developing Digital-Age Project Management Skills to Thrive in Disruptive Teams", 2018. Available at: https://www.pmi.org/- 
/media/pmi/documents/public/pdf/learning/thoughtleadership/pulse/digital-pm-skills.pdf?sc_lang_temp=en

[3] L. Crawford, "Senior management perceptions of project management competence", International Journal of Project Management, vol. 23, 2005, pp 7-16.

[4] L. de-Marcos, E. Garcia-Lopez, and A. Garcia-Cabot, "On the effectiveness of game-like and social approaches in learning: Comparing educational gaming, gamification \& social networking", Computers \& Education, vol. 95, 2016, pp 99113.

[5] K. M. Kapp, "The gamification of learning and instruction: Game-based methods and strategies for training and education", Pfeiffer, 2012, pp.125

[6] S. Deterding, D. Dixon, R. Khaled, and L. Nacke, "From game design elements to gamefulness: defining gamification", Proceedings of the 15th International Academic MindTrek Conference: Envisioning Future Media Environments, 2011, pp. $9-15$.

[7] B. Kim, "The Popularity of Gamification in the Mobile and Social Era”, Library Technology Reports, 2015, pp. 5-9.

[8] J. Kasurinen, and A. Knutas, "Publication trends in gamification: A systematic mapping study", Compute Science Review, vol. 27, 2018, pp.33-44.

[9] K. Seaborn, and D. I. Fels. "Gamification in theory and action: A survey. International Journal of Human-Computer Studies, vol. 74(0), 2015, pp.14-31.

[10] D. Solan, and A. Shtub, "Shall we play a project management game?", ISE: Industrial \& Systems Engineering at Work, vol. 48(11), 2016, pp. 32-37.

[11] E. D. Mekler, F.Brühlmann, A. N. Tuch, and K. Opwis, "Towards understanding the effects of individual gamification elements on intrinsic motivation and performance", Computers in Human Behavior, vol. 71, 2017, pp.525-534.

[12] A. B. Eisingerich, A. Marchand, M. P. Fritze, and L. Donga, "Hook vs hope: How to enhance customer engagement through gamification", International Journal of Research in Marketing, 2019.

[13] P. Buckley, and E. Doyle, "Individualising gamification: An investigation of the impact of learning styles and personality traits on the efficacy of gamification using a prediction market", Computers \& Education, vol. 106, 2017, pp. 43-55.

[14] A. S. Petersen, and A. Ekambaram, "Interaction Experience, Reflection: Enhancing Project Management Training using Serious Games", Proceedings of the ... European conference on knowledge management, 2018.

[15] I. C. Mustata, C. G. Alexe, and C. M. Alexe, "Developing competencies with the general management II business simulation game", Int j simul model, vol. 16, 2017, pp 412 421.

[16] C. Alcelay, "Play and Learn 3D (PAL3D®) A Collaborative Way of Learning Project Management with Minecraft ${ }^{\circledR}$ ", International Journal of Advanced Corporate Learning, vol. 11(2), 2018, pp. 21-23.

[17] R. Van Eck, "Digital game-based learning: it's not just the digital natives who are restless" Educause Review, vol. 41, 2016

[18] E. N. Treher, "Learning with Board Games", The Learning Key Inc, 2011.

[19] T. Lavendera, G. Omonib, R. Laisserc, L. McGowand, S Wakasiakab, G. Macleane, and A. Chimwazaf, "Evaluation of an educational board game to improve use of the partograph in sub-Saharan Africa: A quasi-experimental study", Sexual \& Reproductive Healthcare, vol. 20, 2019, pp. 54-59.
[20] H. Schmucka, and M. K. Arvinb, "Use of a board game format to promote interprofessional learning", Journal of Interprofessional Education \& Practice, vol. 12, 2018, pp. 5156.

[21] T. N. S. Tengku Paris, and R. L. Yussof, "Enhancing Grammar Using Board Game", Procedia - Social and Behavioral Sciences, vol. 68, 2012, pp. 213-221.

[22] S. Parjanen, and M. Hyypiä, "Innotin game supporting collective creativity in innovation activities", Journal of Business Research, vol. 96, 2019, pp. 26-34.

[23] M. T. Azizan, N. Mellon, R. M. Ramli, and S. Yusup, "Improving teamwork skills and enhancing deep learning via development of board game using cooperative learning method in Reaction Engineering course", Education for Chemical Engineers, vol. 22, 2018, pp. 1-13.

[24] A. Khan, and G. Pearce, "A study into the effects of a board game on flow in undergraduate business students", The International Journal of Management Education, vol. 13(3), 2015, pp.193-201.

[25] S. A. M. Yusof, H. M. Radzi, S. N. S. Din, and K. Nurhafizah, "A Study on the Effectiveness of Task Manager Board Game as a Training Tool in Managing Project", AIP Conference Proceedings, vol. 1761, 2016.

[26] D. Bigelow, and J. L. West, "Putting the right project manager on the right job-what competency assessment is all about!", Project Management Institute, 2003. Available at: https://www.pmi.org/learning/library/right-job-competencyassessment-manager-7688

[27] ISO, "Standards in our world", Available at: https://www.iso.org/sites/ConsumersStandards/1 standards.ht ml, 2019.

[28] "Project management competency development framework (PMCDF) 3rd edition", Project Management Institute, 2017.

[29] C. Cartwright, and M. Yinger, "Project management competency development framework - second edition, Project Management Institute, Available at: https://www.pmi.org/learning/library/project-manager competency-development-framework-7376, 2007.

[30] "APM Body of Knowledge" (APMBoK), 7th ed, Association for Project Management, 2018.

[31] "APMI Professional Competency standards for project management", Australian Project Management institute, 2008

[32] "Individual Competence Baseline for Project, Programme and Portfolio Management version 4.0.”, International Project Management Association, 2015, pp.31-32.

[33] D. Rumeser, and M. Emsley, "A systematic review of PROJECT MANAGEMENT SERIOUS GAMES: Identifying gaps, trends, and directions for future research", Journal of Modern Project Management, 2018, pp. 48-59.

[34] A. J. G. Silvius, M. Kampinga, S. Paniagua, and H. Mooic, "Considering sustainability in project management decision making; An investigation using Q-methodology”, International Journal of Project Management, vol. 35(6), 2017, pp. 1133-1150.

[35] B. G. Zulch, "Communication: The Foundation of Project Management”, Procedia Technology, vol. 16, 2014, pp.10001009

[36] R. Hoda, J. Noble., and S. Marshall, "The impact of inadequate customer collaboration on self-organising Agile teams", Information and Software Technology, vol. 53, 2011, pp. 521-534. 